Article

\title{
A Strategic Framework for Transformational Leadership Development in Megaprojects
}

\author{
Abdulla Abdulaziz Al-Subaie ${ }^{1}$, Mohd. Nishat Faisal ${ }^{2, *}$, Belaid Aouni ${ }^{1}$ and Faisal Talib $^{3}$ (D) \\ 1 College of Business \& Economics, Qatar University, Doha 2713, Qatar; abdullas.cbe@gmail.com (A.A.A.-S.); \\ belaid.aouni@qu.edu.qa (B.A.) \\ 2 Department of Management \& Marketing, College of Business \& Economics, Qatar University, \\ Doha 2713, Qatar \\ 3 Department of Mechanical Engineering, ZHCET, Faculty of Engineering \& Technology, \\ Aligarh Muslim University, Aligarh 202002, India; ftalib77@gmail.com \\ * Correspondence: nishat786@qu.edu.qa
}

Citation: Al-Subaie, A.A.; Faisal, M..N.; Aouni, B.; Talib, F. A Strategic Framework for Transformational Leadership Development in Megaprojects. Sustainability 2021, 13, 3480. https://doi.org/10.3390/ su13063480

Academic Editor: Petri Ahokangas

Received: 2 March 2021

Accepted: 19 March 2021

Published: 21 March 2021

Publisher's Note: MDPI stays neutral with regard to jurisdictional claims in published maps and institutional affiliations.

Copyright: (c) 2021 by the authors. Licensee MDPI, Basel, Switzerland. This article is an open access article distributed under the terms and conditions of the Creative Commons Attribution (CC BY) license (https:// creativecommons.org/licenses/by/ $4.0 /)$.

\begin{abstract}
Project managers' leadership has a direct and an indirect effect on project success. Extant literature has established that transformational leadership style positively affects project success in a major way. The main aim of this research is to understand the variables that positively affects transformational leadership development and their interrelationships in megaprojects. The Total Interpretive Structural Model (TISM) methodology is adopted to propose a framework, and Impact Matrix Cross-Reference Multiplication Applied to a Classification (MICMAC) approach is used to examine the strategic nature of the enablers. The research shows that there exists a group of enablers having a high driving power and low dependence, requiring maximum attention and of strategic importance, while another group consists of those variables that have high dependence and are resultant actions. Furthermore, the model explains the relationships among each pair of variables. Organisations dealing in megaprojects would be the major beneficiaries of this study. Policy makers in these organisations would explicitly understand the variables and their interrelationships that needs attention for transformational leadership development. This would help them to prioritize their efforts and implement suitable strategies to focus on the most important variables for developing transformational leaders ultimately leading to project success.
\end{abstract}

Keywords: transformational leadership; total interpretive structural modelling; megaprojects; Qatar; Middle East

\section{Introduction}

Megaprojects can be defined as "a transformational project of over US\$ 1 billion cost proposed by public or private sectors, providing assets that will last for decades and have large impact on societies" [1,2]. In general, "Megaprojects are characterized as endeavors, which are hard to manage, bring in high amounts of uncertainty, and face difficulties in delivering what they have originally planned to" $[3,4]$. Megaprojects are unlike normal or regular projects because of the great difference in complexity, strategy, impact and stakeholders [1]. Hence, understanding project success and factors that contribute to project success is quite crucial in the context of megaprojects. Megaprojects have been researched in the Western and American continents, but are under-researched elsewhere, and having more research from other countries to understand management characteristics and practices in the light of megaprojects is very much encouraged [5].

The role of the project manager is important in project management performance. It has been argued that leadership of project managers have great influence on project performance [6,7]. Leadership qualities are one of the crucial determinants in project teams' work and are considered to be the most researched area in organisational studies [8]. Quite often, project management failure happens due to poor leadership skills of the 
project manager [9]. The project manager's leadership has a direct and an indirect effect on project success. Leadership has an effect on team building and in turn on project success. Leadership also has a direct effect on project success $[10,11]$. However, the project manager's role as a key success factor for project success has not been explored properly in the literature $[7,12,13]$.

Megaprojects involve high stakes and have major social, economic, and environmental impacts [14]. Sustainable practices in the different stages are useful approaches to achieving megaproject success [15]. The transformational leadership approach is considered the most suitable style to nurture followers' attitudes [16], which may include inculcating sustainable or green behaviour among the employees. Improving environmental performance is a major objective in megaproject management; however, a key challenge is translating formal project policies into innovative and spontaneous individual initiatives [17]. Megaprojects not only have a significant impact on the natural environment, but also has profound influence on socio-economic issues [18]. Thereby, adopting sustainable delivery processes is one of the most important objectives in megaprojects [19]. Megaproject sustainability requires a focus on balancing economic profitability, social responsibility, and environment protection [20]. Mittal and Dhar [21] argued that green transformational leadership promotes green creative behaviour of employees, leading to improved sustainability in megaprojects.

There are studies that suggest that projects managers need to possess some common set of soft skills and a certain set of skills depending on the type of project [22]. Bass [23] came up with yet another insightful classification of leadership styles to transactional leadership and transformational leadership. In the transactional style, the concern is for the processes, and in the transformational style, there is a concern for the relationships. In transactional leadership, the leader clarifies and formulates the actions and roles of employees so that they can confidently work to reach a specific project objective. When it comes to transformational leadership, which is centred on charismatic leadership, they increase the awareness level of employees, encouraging them to promote higher quality performances and innovativeness, and to develop themselves as better managers. Studies have shown that the transformational leadership style positively affects project success in a major way $[10,24-26]$. Therefore, the major objectives of this research can be stated as:

- Understand the interrelationship and hierarchy of the enablers positively affecting transformational leadership development in megaprojects with the help of the total interpretive modelling (TISM) technique;

- Analyse the driving and dependent powers of the enablers affecting transformational leadership development (TLD) by using MICMAC analysis; and

- Provide the managerial implications of the results that can be adopted in organisations dealing with megaprojects.

The research was conducted in Qatar, which has emerged as one of the most vibrant economies among the Middle Eastern countries and offers an important setting for management researchers to test existing theories. In 2010, the country was awarded the rights to organize the football World Cup 2022, which has accelerated investments in megaprojects like airports, ports, metro, stadiums, expressways, power plants, man-made islands, and new cities, among other things. This study contributes to the existing literature on transformational leadership and project management by proposing a hierarchical model that relates variables of transformational leadership development in the context of megaprojects. The major contribution of the study is in providing an understanding of the interrelationships among the variables and categorisation based on their impact on other variables influencing transformational leadership development in megaprojects. The research outcome would also provide an explanation of the relationships among the variables. This would improve the understanding of the nature of relationship and provide policy makers a chance to develop suitable plans to improve the critical variables. 


\section{Literature Review}

High level of project complexity and risks are significant obstacles for megaproject success [27]. Transformational leadership is relevant in the project environment as it enables managers to transform their project teams and ultimately affects project performance positively [28]. Transformational leaders can influence their followers using idealized influence, inspirational motivation, intellectual stimulation and individualized consideration [29]. Transformational leadership has been shown to be one of the most effective leadership behaviours in times of change and uncertainty and transformational leaders have also been identified to have a strong, positive influence on subordinates' commitment, which is fundamental to the successful outcome of projects [30]. Transformational leaders play central role in setting project directions, ensuring progress and fulfilment of project goals through organisation-wide cooperation and support [31]. Numerous project challenges demand transformational leadership approaches that drive project management excellence, encourage high-performance teams, and amplify opportunities to project success [32].

Transformational leadership is a concept that has been used in leadership studies since the 1980s, and is said to be the new force in "leadership research" [33]. The relative magnitude of transformational leadership appeared to be quantitatively higher and qualitatively different from the effects specified in other theories collectively referred to as "transactional leadership" [34]. Transformational leaders motivate and inspire their subordinates to perform more than expected [35]. According to path-goal leadership theory [36], when the leadership is transformational in nature, the subordinates get emotionally attached to the leader and will be internally motivated and aroused to follow the leader's behaviour. This results in higher performance of the team and subsequently successful project implementation [37]. Considering the development of transformational leaders as a process, the variables affecting the development are critical for organisations. Therefore, an exhaustive literature review was conducted to derive factors that positively affect the organisations. Finally, after discussion with experts, eleven variables or alternatively enablers of transformational leadership in megaprojects were considered for further analysis in the present research. The eleven enablers are briefly discussed in the following paragraphs.

\subsection{Procedural Justice Mechanism}

Procedural justice is defined as the perception of employees or a leader regarding the fair-mindedness of measures taken to weigh the outcomes they receive for a particular task [38]. It can be visualised as an outcome of leadership behaviour. A review of studies suggests that procedural justice may become a consequence for transformational leadership [39]. According to De Cremer and Tyler [40], there is a positive association between procedural justice and the leadership style. In particular, the transformational type of leadership has been found to be linked with procedural justice. Procedural justice affects people's self-esteem [41] and affects perceptions of employees. Fairness in procedures leads to enhanced contribution of employees [42], thus providing support to the leader. Hence, it can be proposed that procedural justice from the part of organisation and leaders favours transformational leadership behaviour.

\subsection{Training}

Studies in the past have been conducted to examine whether transformational leaders are born or made. However intuitively, training individuals to be more transformational is doable. At the same time, researchers have also opined that transformational leadership behaviour can be dynamically improved $[43,44]$. The effect of training intervention on leadership behaviour along with outcome has been explored in the past [45]. It has been proposed that transformational leadership training intervention affects task performance as well as overall firm performance through leadership behaviour [46,47]. Using an experimental design, Barling et al. [47] evaluated the impact of transformational leadership training intervention on organisational performance. The work of Kelloway [48] echoed the 
above findings and suggested that aspects of transformational leadership can be enhanced using training programs.

\subsection{Positive Job Attitude}

Positive job attitude has been reported as an important determinant of transformational leadership behaviour for two reasons [49]. The first reason is attributed to the fact that job satisfaction motivates employees to take on extra-role tasks and behaviour [50], forming a pivotal part of transformational leadership [51]. Researchers have also suggested that the experience of pleasant feelings at work may be key in determining how transformational leaders will behave [49,52]. Several studies have strengthened the idea that that job attitudes are antecedents to various intended behaviours [50,53], and in consistency with Social Exchange Theory [54], employees may think that due to their positive job attitudes, their jobs give them numerous worthy outcomes and, hence, they develop some motivation to contribute beyond their job assignments. Along similar lines, leaders who are satisfied with their jobs and carry more positive job attitudes may come up with an elevated level of transformational leadership, which is their way of reciprocating. The second reason we posit is the greater degree of consonance (not dissonance) that develops in leaders due to their positive job attitudes. Researchers have opined that job satisfaction provides pathways of pro-social behaviour among leaders, which leads indirectly to transformational leadership [55]. Dissonance leads to absenteeism and turnover; hence, it might not contribute to positive leadership behaviours [56]. In contrast, we posit that leaders that are consonant with their job attitudes may show desirable future transformational leadership, and vice-versa.

\subsection{Cultural Intelligence}

In the current dynamic and multicultural business environment, a leader must appreciate the underlying values associated with varied cultures and then express their needs and motives. In response to such dynamism and the globalisation of firms with rich cultural diversity, researchers have rated cultural intelligence, which may help organisations identify global talent for major projects [57]. This would also enable development of global transformational leaders, i.e., to display transformational leadership behaviours across varied contexts. Earley and Ang [58] explored and defined cultural intelligence (CQ) as the ability of a leader to adapt fruitfully in a cross-cultural work milieu. The concept of cultural intelligence has been recognized as one of the significant predictors of leadership style in international projects [59,60]. For instance, Gurung and Prater [61] stated that organisational leaders find cultural challenges to be hurdles towards foreign operations. Hence, leaders undertaking such endeavours should adopt those leadership approaches that align the drives of a diverse workforce while leveraging organisational objectives [62]. CQ is conceptualised as a set of skills that includes both knowledge and abilities that are supposed to be essential for developing transformational leaders [63]. Elenkov and Manev [64] posited that leaders with high CQ behave more consistently with transformational leadership than those individuals with low CQ. While explaining the role of $C Q$ towards transformational leadership, they argued that such leaders act as role models for expatriate leaders by adapting to different cultures. This ability to swiftly grasp and adapt to these differing meanings accordingly contributes to effective leadership [64].

\subsection{Goal Orientation}

Over the last decade, researchers have shown a great deal of interest in goal orientation [65-67]. Goal orientation refers to the goals individuals implicitly pursue while attaining performance outcomes [68]. Dweck [69] originally suggested that the people with goals orientation pursue events and their interpretation. This has led to the identification of learning and performance orientation as components of goal orientation [68,70]. Individuals with learning goal orientation try to understand new things and enhance their competence level for specific tasks. Tabernero and Wood [71] found that learning-oriented 
individuals develop better self-efficacy and set goals that are more challenging. This behaviour is found to be in line with transformational behaviour of leaders. In addition, it has been envisaged in the past that transactional leaders perform better towards achieving competitive goals [72]. From this viewpoint, it can be assessed that goal orientation is one of the key enablers and motivational functions for transformational leadership.

\subsection{Handling Uncertain Business Environments}

The dynamics and volatility of the external business environment are generally related to the uncertainty of the external environment affecting businesses. When an organisation starts losing business or the environment is turbulent, a change in leading the organisation is pivotal $[73,74]$. External factors like technological changes and global competition force companies to rethink and delineate the strategies [75]. It has been posited by researchers that uncertainty and volatility in the business environment lead to enhancement of the transformational leadership behaviour [76], and it is the environmental changes that act as enablers towards transformational leadership. To cope with uncertain external environments, transformational leadership emerges to re-align the business. This revolutionary type of transformational leadership helps in developing human capital along with the creation of strategic flexibility [77]. There is a positive association between revolutionary transformational leadership behaviour and environmental circumstances [78]. Thus, the preceding literature offers the basis for proposing a positive effect of business challenges and uncertainty towards transformational leadership behaviour.

\subsection{Adaptability}

According to Bass [23], to transform means the ability to change and embrace the change, and it lies at the heart of transformational leadership. It has been highlighted by many that individuals who possess a desire to change are better able to gauge situations and act accordingly $[79,80]$. Keller [81] reported that employees that rated high on embracing change tend to recall behaviours pertaining to transformational leadership. Transformational leaders inspect the situation and are inquisitive. Similar characteristics have been found in individuals who were high on openness to experience [80,82]. In addition, they are naturally motivated toward achievement, relish being intellectually stimulated, and are excited by transformational learning [83]. Brummelhuis and Bakker [84] suggested that openness to experience is a key enabler towards transformational learning, providing effective and efficient handling of resources thorough facilitated selection. Similar results were reported by Hildenbrand [85]. Intellectual stimulation has been explored as a component of transformational leadership style [86] and since openness to experience is linked with the merits of innovation acceptance [87], the existence of such characteristics should trigger this trait via intellectual stimulation.

\subsection{Organisational Structure}

According to leadership contingency theory, the effectiveness of leadership behaviour sometimes depends on the various contextual factors of a particular organisation [88,89]. Organisational structure is found to be on equal footing with the contextual factors category and is significant in enabling the acceptance of leadership types [90,91]. Contextual factors depend upon resources and contingencies. Similarly, organisational structure is associated with allocation of resources and its coordination as well [92]. James and Jones [93] defined organisational structure as: "the enduring characteristics of an organization reflected by the distribution of units and positions within the organization and their systematic relationships to each other". The existing literature suggests that a considerable amount of research has been conducted examining the role and consequences of transformational leadership [94,95], but studies focussing on its enablers and antecedents are few and far between. Organisational structure has been reported to be one of the predictors of transformational leadership [96]. Structural characteristics related to transformational leadership may include distribution of authority, formalisation of rules, and downward 
communication $[97,98]$. Similarly, the structure of bureaucratic organisations has been investigated as a significant variable towards transformational leadership [90].

\subsection{International Experience}

In conjunction with cultural intelligence, international experience is also considered to be an antecedent to transformational leadership [99,100]. In multicultural settings, international experience is often defined as an intermediate variable towards leadership outcomes [101]. It has been suggested that the interplay of international experience is required to be considered in order to assess the strength of transformational leadership [63]. Studies in the past have empirically proven the relevance of international experience towards global leadership. It has been suggested that international experience leads to an increase in the managerial competencies required for leadership [102]. International experience has previously been investigated as a variable affecting transformational leadership style [66], and it was found to have a positive influence over transformation style of leadership [103]. Previous studies have also revealed that international experience presents the opportunity to experience a leadership style, thus motivating employees [104].

\subsection{Communication}

One behaviour of transformational leadership is the ability to communicate a desirable, inspirational, and attainable vision. Communication helps transformational leaders in demonstrating inherent attributes like openness in conversation, participation and feedback, and innovation [105]. Communication style has been advocated as an enabler towards transformational leadership behaviour in order to achieve organisational outcomes [106]. Similar results were reported by Berson and Avolio [107], providing a positive link between communication competence and transformational leadership style. They found that leaders who are good communicators have the ability to turn into transformational leaders. According to Barge's communication-centred approach to leadership [108], leadership itself is a form of communication, and is enacted through communication. It can be deduced that transformational leadership depends upon communication competence. Moreover, an open two-way communication system welcomes feedback and helps a leader in collaborating and nurturing employee satisfaction [105]. In the same vein, [109] claimed that communication competence is correlated with every aspect of transformational leadership (charisma, individual consideration, intellectual stimulation). Communication also helps transformational leaders enable the process of self-persuasion among employees. In this way, transformational leaders foster employees in working towards the core purpose of organisation. Hence, communication style (whether symmetrical or asymmetrical) is the deciding factor in differentiating the communication competence and language of a leader [110].

\subsection{Future Focus (Focus on Future Outcomes/Consequences)}

Transformational leaders identify and articulate a vision by fostering team goals and setting high standards. This is done via consideration of future outcomes or consequences [111]. In the context of leadership, future focus is the level to which leaders consider the future outcomes of their present behaviour. It is the degree to which leaders are influenced by considering the potential success of results. Consideration of future outcomes strengthens transformational leadership behaviour by rating present actions in terms of future consequences [112]. Zhang et al. [113] investigated the effect of future consequences on transformational leadership by examining the relationships between them and found a positive influence of future consequences on transformational style of leadership.

\section{Methodology}

The present study adopted a two-stage methodology. The first stage consisted of identification and selection of enablers associated with the TLD in megaprojects. The 
second stage consisted of understanding the interrelationships of TLD enablers, followed by the model development based on the TISM technique and providing implications to managers involved in megaprojects for developing transformational leaders. The literature review revealed several enablers of transformational leadership development; however, for the present study, the variables were selected on the basis of experts' opinions with respect to their applicability to megaprojects. Next, the TISM technique was applied to develop the interrelationships for the enablers of TLD and to construct their hierarchical model for megaprojects. TISM was preferred over ISM because of the following reasons [114,115]:

- ISM interprets only the nodes, whereas TISM interprets both nodes and links in the digraph;

- $\quad$ TISM shows some important transitivity links, which can give a better explanatory framework (Figure 1) compared to ISM, where all transitivity links are removed;

- Fewer experts are needed in TISM development when compared with other multi criteria decision modelling (MCDM) techniques; and

- Finally, TISM answers three key questions of theory building, i.e., what, how, and why.

TISM is now a widely acknowledged technique that is applied to different research domains, including healthcare organisations [116], big data analytics [117], higher education institutions [118], additive manufacturing [119], waste management [120], etc., to name a few. Considering the extensive use of the TISM approach in the literature to analyse problems affected by multiple variables, this study has used the TISM technique to develop a hierarchical structural model of TLD enablers implementation in megaprojects. The various steps involved in TISM technique for modelling TLD enablers in megaprojects are presented in the next section.

\section{Data Analysis and Results}

\subsection{Data Collection}

This study focuses primarily on the performance of megaprojects through the implementation of TLD enablers. The data for this study were collected by organizing personal interviews using an open-ended questionnaire during the period September-December 2020. The prime source of data was the megaprojects organisations operating in Qatar. Qatar is currently a hub for megaprojects, as it is the host of football World Cup 2022. Infrastructure, stadiums and metro are some of the megaprojects underway in Qatar. The organisations that were chosen for our study were based upon researchers' prior experience and personal contacts with people working in these organisations. The experts were from top management, with a working experience in projects of more than 15 years. A face-to-face meeting invitation was mailed to 13 experts, and after a few reminders and requests by telephone, 9 experts finally joined the brainstorming sessions. The details of the experts from whom inputs were solicited are presented in Table 1 The size of the experts group was considered adequate, as per other studies employing TISM.

Table 1. Expert details.

\begin{tabular}{cccc}
\hline S. No. & Position & Work Experience (Years) & Size of Organisation \\
\hline 1. & Acting Chief of Program Delivery & 17 & Large \\
2. & Senior Director of QSHESE & 21 & Large \\
3. & Project Director LRT & 16 & Large \\
4. & Senior Manager LRT & 34 & Large \\
5. & Project Director-RLS/MS & 31 & Large \\
6. & Project Director & 30 & Large \\
7. & Director-Commercial & 29 & Large \\
8. & Contract Administration Manager & 23 & Large \\
9. & Project Director & 35 & Large \\
\hline
\end{tabular}




\subsection{Identification and Definition of Enablers}

Defining and identification of enablers that are significant to the problem or issue is the starting point of the TISM technique $[118,119]$. Eleven enablers were identified as being related to TLD in megaprojects on the basis of a review of the existing literature and the experts' opinion, as discussed in Section 2.

\subsection{Establishing Contextual Relationships}

The contextual relationships among the TLD enablers of TLD in megaprojects were established by considering the opinions of the industry experts. A brainstorming session using a questionnaire was developed and distributed among the chosen experts (see Section 4.1). The opinions were recorded in the form of 'YES' or 'NO' responses, depending on whether the enabler influences the other enabler. For example, if enabler 1 influences enabler 2, then the contextual relationship is ' 1 '; otherwise, it is ' 0 '.

\subsection{Interpretive Logic of Pairwise Comparison}

An interaction between each combination of enablers is developed via expert assessment in the form of a relationship matrix so that the significant impact of each enabler on other enablers can be obtained. Therefore, for a total of ' $n$ ' enablers, the number of comparisons will be $n(n-1)$ to make an 'interpretive logic knowledge-base'. This interpretive logic knowledge-base matrix, which was derived from the experts' opinions, is shown in Table 2. For example, in Table 2, enabler E2 (Training) directly impacts enabler E6 (Handling uncertain business environment); therefore, the entry in Table 2 for the relationship between these two variables is ' $\mathrm{V}$ '. In cases where variables like E4 (Cultural Intelligence) and E10 (Communication) affect each other, the relationship will be ' $X$ ', while in cases where there is no relationship, such as between E1 and E2, the relationship will be ' $\mathrm{O}$ '.

Table 2. Structural self-interaction matrix (SSIM).

\begin{tabular}{|c|c|c|c|c|c|c|c|c|c|c|c|c|}
\hline Enabler Symbol & Enabler Name & 11 & 10 & 9 & 8 & 7 & 6 & 5 & 4 & 3 & 2 & 1 \\
\hline E1 & $\begin{array}{l}\text { Procedural Justice } \\
\text { Mechanism }\end{array}$ & V & $\mathrm{V}$ & $\mathrm{O}$ & A & $\mathrm{O}$ & $\mathrm{V}$ & V & $\mathrm{O}$ & $\mathrm{V}$ & $\mathrm{O}$ & - \\
\hline E2 & Training & V & $\mathrm{V}$ & $\mathrm{O}$ & A & $\mathrm{V}$ & $\mathrm{V}$ & $\mathrm{V}$ & $\mathrm{V}$ & V & - & \\
\hline E3 & $\begin{array}{l}\text { Positive Job Attitude and } \\
\text { Satisfaction }\end{array}$ & $\mathrm{A}$ & $\mathrm{A}$ & A & $\mathrm{A}$ & $\mathrm{A}$ & $\mathrm{A}$ & $\mathrm{O}$ & A & - & & \\
\hline E4 & Cultural Intelligence & $x$ & $x$ & $\mathrm{~A}$ & $\mathrm{~A}$ & $\mathrm{~V}$ & V & $\mathrm{V}$ & - & & & \\
\hline E5 & Goal Orientation & $\mathrm{A}$ & $\mathrm{A}$ & A & $\mathrm{A}$ & $\mathrm{A}$ & $\mathrm{A}$ & - & & & & \\
\hline E6 & $\begin{array}{c}\text { Handling Uncertain Business } \\
\text { Environment }\end{array}$ & $\mathrm{A}$ & $\mathrm{A}$ & $\mathrm{O}$ & $\mathrm{A}$ & $x$ & - & & & & & \\
\hline E7 & Adaptability & A & A & A & A & - & & & & & & \\
\hline E8 & Organisational Structure & $\mathrm{V}$ & $\mathrm{V}$ & $\mathrm{V}$ & - & & & & & & & \\
\hline E9 & International Experience & $\mathrm{O}$ & $\mathrm{V}$ & - & & & & & & & & \\
\hline E10 & Communication & $x$ & - & & & & & & & & & \\
\hline E11 & $\begin{array}{c}\text { Future Focus (Focus on } \\
\text { Future } \\
\text { Outcomes/Consequences) }\end{array}$ & - & & & & & & & & & & \\
\hline
\end{tabular}

Relationship Explanation: V: Enabler $i$ will help achieve enabler $j$; A: Enabler $j$ will help achieve enabler $i$; X: Enablers $i$ and $j$ will help achieve each other; and O: Enablers $i$ and $j$ are unrelated.

\subsection{Reachability Matrix and Transitivity Review}

The initial reachability matrix was deduced from Table 2 by converting $\mathrm{O}, \mathrm{A}, \mathrm{X}$ entries into binary numbers [121]. The initial reachability matrix was reviewed for the transitivity rule, which implies that if enabler 1 influences enabler 2 and enabler 2 influences enabler 3 , 
then enabler 1 will influence enabler 3. After reviewing the transitivity rule, the final reachability matrix was obtained, as presented in Table 3.

Table 3. Final reachability matrix.

\begin{tabular}{|c|c|c|c|c|c|c|c|c|c|c|c|c|c|c|}
\hline Enabler Symbol & Enabler Name & 1 & 2 & 3 & 4 & 5 & 6 & 7 & 8 & 9 & 10 & 11 & Driving Power & Rank \\
\hline E1 & $\begin{array}{l}\text { Procedural Justice } \\
\text { Mechanism }\end{array}$ & 1 & 0 & 1 & $1 *$ & 1 & 1 & $1 *$ & 0 & 0 & 1 & 1 & 8 & II \\
\hline E2 & Training & 0 & 1 & 1 & 1 & 1 & 1 & 1 & 0 & 0 & 1 & 1 & 8 & II \\
\hline E3 & $\begin{array}{l}\text { Positive Job Attitude } \\
\text { and Satisfaction }\end{array}$ & 0 & 0 & 1 & 0 & 0 & 0 & 0 & 0 & 0 & 0 & 0 & 1 & $\mathrm{~V}$ \\
\hline E4 & Cultural Intelligence & 0 & 0 & 1 & 1 & 1 & 1 & 1 & 0 & 0 & 1 & 1 & 7 & III \\
\hline E5 & Goal Orientation & 0 & 0 & 0 & 0 & 1 & 0 & 0 & 0 & 0 & 0 & 0 & 1 & $\mathrm{~V}$ \\
\hline E6 & $\begin{array}{l}\text { Handling Uncertain } \\
\text { Business } \\
\text { Environment }\end{array}$ & 0 & 0 & 1 & 0 & 1 & 1 & 1 & 0 & 0 & 0 & 0 & 4 & IV \\
\hline E7 & Adaptability & 0 & 0 & 1 & 0 & 1 & 1 & 1 & 0 & 0 & 0 & 0 & 4 & IV \\
\hline E8 & $\begin{array}{l}\text { Organisational } \\
\text { Structure }\end{array}$ & 1 & 1 & 1 & 1 & 1 & 1 & 1 & 1 & 1 & 1 & 1 & 11 & I \\
\hline E9 & $\begin{array}{l}\text { International } \\
\text { Experience }\end{array}$ & 0 & 0 & 1 & 1 & 1 & $1^{*}$ & 1 & 0 & 1 & 1 & $1 *$ & 8 & II \\
\hline E10 & Communication & 0 & 0 & 1 & 1 & 1 & 1 & 1 & 0 & 0 & 1 & 1 & 7 & III \\
\hline \multirow[t]{3}{*}{ E11 } & $\begin{array}{l}\text { Future Focus (Focus } \\
\text { on Future Out- } \\
\text { comes/Consequences) }\end{array}$ & 0 & 0 & 1 & 1 & 1 & 1 & 1 & 0 & 0 & 1 & 1 & 7 & III \\
\hline & Dependence Power & 2 & 2 & 10 & 7 & 10 & 9 & 9 & 1 & 2 & 7 & 7 & 66 & \\
\hline & Rank & IV & IV & I & III & I & II & II & V & IV & III & III & & \\
\hline
\end{tabular}

\subsection{Partitioning the Reachability Matrix (Level Partition)}

The purpose of level partitioning is to identify the level of each enabler [119], which is necessary for constructing final TISM model. For level partitioning, the final reachability matrix (Table 3) is used and split into different levels. This is carried out by performing a series of iterations for each enabler, leading to the emergence of various levels, as shown in Table 4. An in-depth explanation of the level partition procedure can be found in [121-123].

\subsection{Interpretation of Relationship}

This can be considered as the most value-adding step of TISM. In this step, the interpretation of relationship among enablers' is enunciated. This is the additional step in TISM as compared to ISM. In this step, TISM describes how enablers influence each other, a critical step that is not considered in ISM. This makes it easier to understand the relationships and to develop suitable strategies to improve them. This interpretation of the relationships is presented in the interpretive matrix in Table 5.

\subsection{Creating Total Interpretive Structural Model}

The final TISM model was developed with the help of the final reachability matrix and the level partitions [124]. In this model, only significant transitivity and direct links are considered. Enablers having a direct relationship are connected through solid lines, while transitivity links are represented by broken lines. The TISM digraph model is shown in Figure 1. For the TISM model, the causal thinking behind the direct and significant transitive links can be understood from Table 5 . 
Table 4. Enablers of transformational leadership development level iterations i-v.

\begin{tabular}{|c|c|c|c|c|c|}
\hline Enabler Symbol & Enabler Name & $\begin{array}{c}\text { Reachability Set } \\
\text { R(Bi) }\end{array}$ & $\begin{array}{c}\text { Antecedent Set A } \\
\text { (Bi) }\end{array}$ & $\begin{array}{l}\text { Intersection Set } \\
\mathbf{R}(\mathbf{B i}) \cap \mathbf{A}(\mathbf{B i})\end{array}$ & Level \\
\hline E1 & $\begin{array}{l}\text { Procedural Justice } \\
\text { Mechanism }\end{array}$ & E1 & E1, E8 & E1 & IV \\
\hline E2 & Training & E2 & $\mathrm{E} 2, \mathrm{E} 8$ & E2 & IV \\
\hline E3 & $\begin{array}{l}\text { Positive Job Attitude } \\
\text { and Satisfaction }\end{array}$ & E3 & $\begin{array}{l}\text { E1, E2, E3, E4, E6, } \\
\text { E7, E8, E9, E10, E11 }\end{array}$ & E3 & $\mathbf{I}$ \\
\hline $\mathrm{E} 4$ & Cultural Intelligence & E4, E10, E11 & $\begin{array}{l}\text { E1, E2, E4, E8, E9, } \\
\text { E10, E11 }\end{array}$ & E4, E10, E11 & III \\
\hline E5 & Goal Orientation & E5 & $\begin{array}{l}\text { E1, E2, E4, E5, E6, } \\
\text { E7, E8, E9, E10, E11 }\end{array}$ & E5 & $\mathbf{I}$ \\
\hline E6 & $\begin{array}{l}\text { Handling Uncertain } \\
\text { Business Environment }\end{array}$ & E6, E7 & $\begin{array}{c}\text { E1, E2, E4, E6, E7, } \\
\text { E8, E9, E10, E11 }\end{array}$ & E6, E7 & II \\
\hline E7 & Adaptability & E6, E7 & $\begin{array}{c}\text { E1, E2, E4, E6, E7, } \\
\text { E8, E9, E10, E11 }\end{array}$ & E6, E7 & II \\
\hline E8 & $\begin{array}{l}\text { Organisational } \\
\text { Structure }\end{array}$ & E8 & E8 & E8 & $\mathbf{V}$ \\
\hline E9 & $\begin{array}{l}\text { International } \\
\text { Experience }\end{array}$ & E9 & E8, E9 & E9 & IV \\
\hline E10 & Communication & E4, E10, E11 & $\begin{array}{l}\text { E1, E2, E4, E8, E9, } \\
\text { E10, E11 }\end{array}$ & E4, E10, E11 & III \\
\hline E11 & $\begin{array}{c}\text { Future Focus (Focus } \\
\text { on Future Out- } \\
\text { comes/Consequences) }\end{array}$ & E4, E10, E11 & $\begin{array}{c}\text { E1, E2, E4, E8, E9, } \\
\text { E10, E11 }\end{array}$ & E4, E10, E11 & III \\
\hline
\end{tabular}

Table 5. Interpretive matrix for TISM.

\begin{tabular}{|c|c|c|c|c|c|c|}
\hline Enabler No. & E1 & E2 & E3 & E4 & E5 & E6 \\
\hline E1 & - & - & $\begin{array}{l}\text { Procedural Justice } \\
\text { reinforces the sense } \\
\text { of fairness among } \\
\text { employees leading } \\
\text { to improvement in } \\
\text { Job Attitude and } \\
\text { Satisfaction. }\end{array}$ & - & $\begin{array}{l}\text { Procedural Justice } \\
\text { keeps employees' } \\
\text { minds free to } \\
\text { understand new things } \\
\text { and enhance their } \\
\text { competences. }\end{array}$ & $\begin{array}{l}\text { When employees } \\
\text { perceive that } \\
\text { organisation has } \\
\text { Procedural Justice } \\
\text { Mechanisms in place } \\
\text { they will be ready to } \\
\text { take new challenges. }\end{array}$ \\
\hline E2 & - & - & $\begin{array}{l}\text { Training is vital to } \\
\text { improve employees' } \\
\text { skills, leading to job } \\
\text { satisfaction. }\end{array}$ & $\begin{array}{l}\text { Organisations with } \\
\text { multicultural } \\
\text { workforces need } \\
\text { specific training to } \\
\text { sensitize them } \\
\text { about variety of } \\
\text { cultures. }\end{array}$ & $\begin{array}{l}\text { Right type of Training } \\
\text { would help to improve } \\
\text { goal orientation. }\end{array}$ & $\begin{array}{l}\text { Dynamic business } \\
\text { environment requires } \\
\text { specific skill sets that } \\
\text { would help employees } \\
\text { to handle uncertain } \\
\text { business environment. }\end{array}$ \\
\hline E3 & - & - & - & - & - & - \\
\hline $\mathrm{E} 4$ & - & - & $\begin{array}{c}\text { Cultural } \\
\text { Intelligence } \\
\text { includes skills that } \\
\text { would improve Job } \\
\text { Attitude and } \\
\text { Satisfaction. }\end{array}$ & - & $\begin{array}{l}\text { Cultural Intelligence } \\
\text { helps to adapt } \\
\text { effectively in } \\
\text { cross-cultural work } \\
\text { milieu, leading to } \\
\text { improvement in } \\
\text { employees' ability to } \\
\text { understand new things, } \\
\text { a critical component of } \\
\text { Goal Orientation. }\end{array}$ & $\begin{array}{l}\text { Cultural Intelligence } \\
\text { helps to deal with } \\
\text { uncertain business } \\
\text { environment, as it } \\
\text { improves adaptation to } \\
\text { new situations quickly. }\end{array}$ \\
\hline E5 & - & - & - & - & - & - \\
\hline
\end{tabular}


Table 5. Cont.

\begin{tabular}{|c|c|c|c|c|c|c|}
\hline Enabler No. & E1 & E2 & E3 & E4 & E5 & E6 \\
\hline E6 & - & - & $\begin{array}{l}\text { Handling Uncertain } \\
\text { Business } \\
\text { Environment brings } \\
\text { new challenges that } \\
\text { facilitate } \\
\text { elimination of } \\
\text { monotony and a } \\
\text { sense of } \\
\text { achievement, } \\
\text { leading to } \\
\text { improvement in Job } \\
\text { Attitude and } \\
\text { Satisfaction. }\end{array}$ & - & $\begin{array}{l}\text { Handling Uncertain } \\
\text { Business Environment } \\
\text { provides opportunities } \\
\text { to understand new } \\
\text { things, thereby } \\
\text { improving Goal } \\
\text { Orientation. }\end{array}$ & - \\
\hline E7 & - & - & $\begin{array}{c}\text { Adaptability } \\
\text { provides motivation } \\
\text { for achievement, } \\
\text { leading to Positive } \\
\text { Attitude and } \\
\text { Satisfaction. }\end{array}$ & - & $\begin{array}{l}\text { Adaptability provides } \\
\text { employees with } \\
\text { openness to experience, } \\
\text { leading to } \\
\text { understanding new } \\
\text { things, thereby } \\
\text { facilitating Goal } \\
\text { Orientation. }\end{array}$ & $\begin{array}{l}\text { Adaptability facilitates } \\
\text { innovative learning } \\
\text { that enables effective } \\
\text { Handling of } \\
\text { Uncertainty. }\end{array}$ \\
\hline E8 & $\begin{array}{l}\text { Organisation } \\
\text { structure consists of } \\
\text { formalisation of } \\
\text { rules that facilitate } \\
\text { Procedural Justice } \\
\text { Mechanism, as } \\
\text { employees can refer } \\
\text { back to rules and } \\
\text { understand the } \\
\text { decision in a } \\
\text { specific situation. }\end{array}$ & $\begin{array}{l}\text { To make employees } \\
\text { understand formal } \\
\text { rules, and how } \\
\text { authority is } \\
\text { distributed in an } \\
\text { Organisation } \\
\text { structure, training is } \\
\text { required. }\end{array}$ & $\begin{array}{l}\text { Organisation } \\
\text { Structure is } \\
\text { associated with } \\
\text { allocation of } \\
\text { resources, as well as } \\
\text { its coordination and } \\
\text { communication, all } \\
\text { of which lead to } \\
\text { Positive Job } \\
\text { Attitude and } \\
\text { Satisfaction. }\end{array}$ & $\begin{array}{l}\text { Allocation of } \\
\text { resources and their } \\
\text { coordination } \\
\text { effectively supports } \\
\text { Cultural } \\
\text { Intelligence. }\end{array}$ & $\begin{array}{l}\text { Effective distribution of } \\
\text { units and positions } \\
\text { within the organisation } \\
\text { enables Goal } \\
\text { Orientation among } \\
\text { employees. }\end{array}$ & $\begin{array}{c}\text { Effective } \\
\text { communication as part } \\
\text { of Organisation } \\
\text { Structure effectively } \\
\text { helps employees to } \\
\text { handle uncertain } \\
\text { business environment. }\end{array}$ \\
\hline E9 & - & - & $\begin{array}{l}\text { International } \\
\text { Experience } \\
\text { provides employees } \\
\text { various experiences } \\
\text { from performing } \\
\text { their jobs, leading to } \\
\text { Positive Job } \\
\text { Attitude and } \\
\text { Satisfaction. }\end{array}$ & $\begin{array}{c}\text { Working on } \\
\text { international } \\
\text { assignments helps } \\
\text { employees } \\
\text { appreciate values of } \\
\text { various cultures, } \\
\text { leading to an } \\
\text { improvement in } \\
\text { their Cultural } \\
\text { Intelligence. }\end{array}$ & $\begin{array}{l}\text { International } \\
\text { Experience provides } \\
\text { opportunities to } \\
\text { understand new things, } \\
\text { improving Goal } \\
\text { Orientation. }\end{array}$ & - \\
\hline E10 & - & - & $\begin{array}{c}\text { Effective } \\
\text { Communication } \\
\text { provides important } \\
\text { feedback to } \\
\text { employees, leading } \\
\text { to Positive Job } \\
\text { Attitude and } \\
\text { Satisfaction. }\end{array}$ & $\begin{array}{l}\text { Communication } \\
\text { among employees } \\
\text { provides } \\
\text { opportunities to } \\
\text { understand people } \\
\text { from a variety of } \\
\text { cultures, thereby } \\
\text { improving their } \\
\text { Cultural } \\
\text { Intelligence. }\end{array}$ & $\begin{array}{l}\text { Communication among } \\
\text { employees helps them } \\
\text { to set their goals, } \\
\text { leading to } \\
\text { improvement in Goal } \\
\text { Orientation. }\end{array}$ & $\begin{array}{l}\text { To Handle Uncertain } \\
\text { Business Environment, } \\
\text { Communication is an } \\
\text { important variable, as } \\
\text { this helps employees } \\
\text { understand where the } \\
\text { information resides in } \\
\text { the organisation and } \\
\text { with whom. }\end{array}$ \\
\hline E11 & - & - & $\begin{array}{l}\text { Future Focus helps } \\
\text { foster team goals } \\
\text { and set high } \\
\text { standards. This } \\
\text { would lead to } \\
\text { Positive Job } \\
\text { Attitude and } \\
\text { Satisfaction. }\end{array}$ & $\begin{array}{l}\text { Evaluation of future } \\
\text { outcomes also } \\
\text { requires } \\
\text { consideration of the } \\
\text { impact on culture, } \\
\text { thereby improving } \\
\text { cultural } \\
\text { intelligence. }\end{array}$ & $\begin{array}{l}\text { Future Focus allows } \\
\text { leaders to rate their } \\
\text { present actions by } \\
\text { future consequences, } \\
\text { thereby positively } \\
\text { affecting Goal } \\
\text { Orientation. }\end{array}$ & $\begin{array}{l}\text { Future Focus helps } \\
\text { leaders to consider } \\
\text { future outcomes of } \\
\text { their present behaviour. } \\
\text { This would assist in } \\
\text { Handling Uncertain } \\
\text { Business Environment. }\end{array}$ \\
\hline Enabler No. & E7 & E8 & E9 & E10 & E11 & \\
\hline E1 & - & - & - & $\begin{array}{l}\text { Procedural Justice } \\
\text { affects people's } \\
\text { self-esteem, which } \\
\text { is positively related } \\
\text { to communication } \\
\text { in the organisation. }\end{array}$ & $\begin{array}{l}\text { Leaders will only be } \\
\text { able to create team } \\
\text { goals and set high } \\
\text { standards when } \\
\text { Procedural Justice } \\
\text { exists in the } \\
\text { organisation }\end{array}$ & \\
\hline
\end{tabular}


Table 5. Cont

\begin{tabular}{|c|c|c|c|c|c|c|}
\hline Enabler No. & E1 & E2 & E3 & E4 & E5 & E6 \\
\hline E2 & $\begin{array}{l}\text { Training provides } \\
\text { employees with } \\
\text { skills to adapt and } \\
\text { embrace change. }\end{array}$ & - & - & $\begin{array}{l}\text { Formal Training } \\
\text { helps employees } \\
\text { understand the } \\
\text { merits of effective } \\
\text { communication. It } \\
\text { also helps } \\
\text { employees to } \\
\text { understand the } \\
\text { chan- } \\
\text { nels / mechanisms } \\
\text { that facilitate } \\
\text { communication } \\
\text { among themselves } \\
\text { to improve } \\
\text { organisational } \\
\text { outcomes. }\end{array}$ & $\begin{array}{l}\text { Training helps } \\
\text { employees to set team } \\
\text { goals and also to } \\
\text { evaluate the future } \\
\text { outcomes of their } \\
\text { present behaviour. }\end{array}$ & \\
\hline E3 & - & - & - & - & - & \\
\hline $\mathrm{E} 4$ & $\begin{array}{c}\text { Cultural } \\
\text { Intelligence helps } \\
\text { employees to } \\
\text { appreciate the } \\
\text { variety of culture } \\
\text { and their values. } \\
\text { This improves their } \\
\text { openness to } \\
\text { experience and } \\
\text { adaptability. }\end{array}$ & - & - & $\begin{array}{l}\text { Understanding of } \\
\text { diversity of the } \\
\text { organisation and } \\
\text { cultural values } \\
\text { would facilitate } \\
\text { communication. }\end{array}$ & $\begin{array}{l}\text { Adapting to a variety } \\
\text { of cultures supports } \\
\text { future focus, as it helps } \\
\text { to evaluate the results } \\
\text { in a holistic manner. }\end{array}$ & \\
\hline E5 & - & - & - & - & - & \\
\hline E6 & $\begin{array}{l}\text { Handling Uncertain } \\
\text { Business } \\
\text { Environment } \\
\text { requires employees } \\
\text { to be flexible in } \\
\text { their approach. }\end{array}$ & - & - & - & - & \\
\hline E7 & - & - & - & - & - & \\
\hline E8 & $\begin{array}{l}\text { Clear downward } \\
\text { communication is a } \\
\text { positive element } \\
\text { that would affect } \\
\text { adaptability. }\end{array}$ & - & $\begin{array}{c}\text { Allocation of } \\
\text { resources and } \\
\text { distribution of } \\
\text { authority would } \\
\text { create opportunities } \\
\text { for many } \\
\text { employees to have a } \\
\text { chance of working } \\
\text { in an international } \\
\text { project. }\end{array}$ & $\begin{array}{l}\text { Formalisation of } \\
\text { rules, as an } \\
\text { important aspect of } \\
\text { Organisational } \\
\text { Structure, assists in } \\
\text { effective } \\
\text { communication } \\
\text { among employees. }\end{array}$ & $\begin{array}{l}\text { Organisational } \\
\text { Structure facilitates } \\
\text { distribution of units } \\
\text { and positions within } \\
\text { the organisation and } \\
\text { their relationships, } \\
\text { fostering team goals } \\
\text { and setting high } \\
\text { standards. }\end{array}$ & \\
\hline E9 & $\begin{array}{l}\text { International } \\
\text { Experience provides } \\
\text { exposure to a } \\
\text { variety of working } \\
\text { environments, } \\
\text { leading to } \\
\text { improvement in } \\
\text { adaptability. }\end{array}$ & - & - & $\begin{array}{l}\text { Employees would } \\
\text { find a variety of } \\
\text { mechanisms to } \\
\text { communicate while } \\
\text { working on an } \\
\text { international } \\
\text { assignment. This } \\
\text { would help them } \\
\text { understand how to } \\
\text { improve } \\
\text { communication in } \\
\text { their organisation. }\end{array}$ & - & \\
\hline E10 & $\begin{array}{l}\text { Communication } \\
\text { supports openness } \\
\text { to experience, } \\
\text { which is a key } \\
\text { enabler of } \\
\text { adaptability. }\end{array}$ & - & - & - & $\begin{array}{l}\text { An open two-way } \\
\text { communication system } \\
\text { supports feedback that } \\
\text { would make easier for } \\
\text { employees to evaluate } \\
\text { the future outcomes of } \\
\text { their present behaviour. }\end{array}$ & \\
\hline E11 & $\begin{array}{l}\text { Future Focus } \\
\text { requires evaluation } \\
\text { and adjustments in } \\
\text { present behaviour } \\
\text { in consideration of } \\
\text { future results. This } \\
\text { would facilitate } \\
\text { adaptability among } \\
\text { employees. }\end{array}$ & - & - & $\begin{array}{l}\text { Future focus cannot } \\
\text { take place in } \\
\text { isolation; it requires } \\
\text { inputs from } \\
\text { colleagues. This } \\
\text { would assist in } \\
\text { improving } \\
\text { communication in } \\
\text { the organisation }\end{array}$ & - & \\
\hline
\end{tabular}




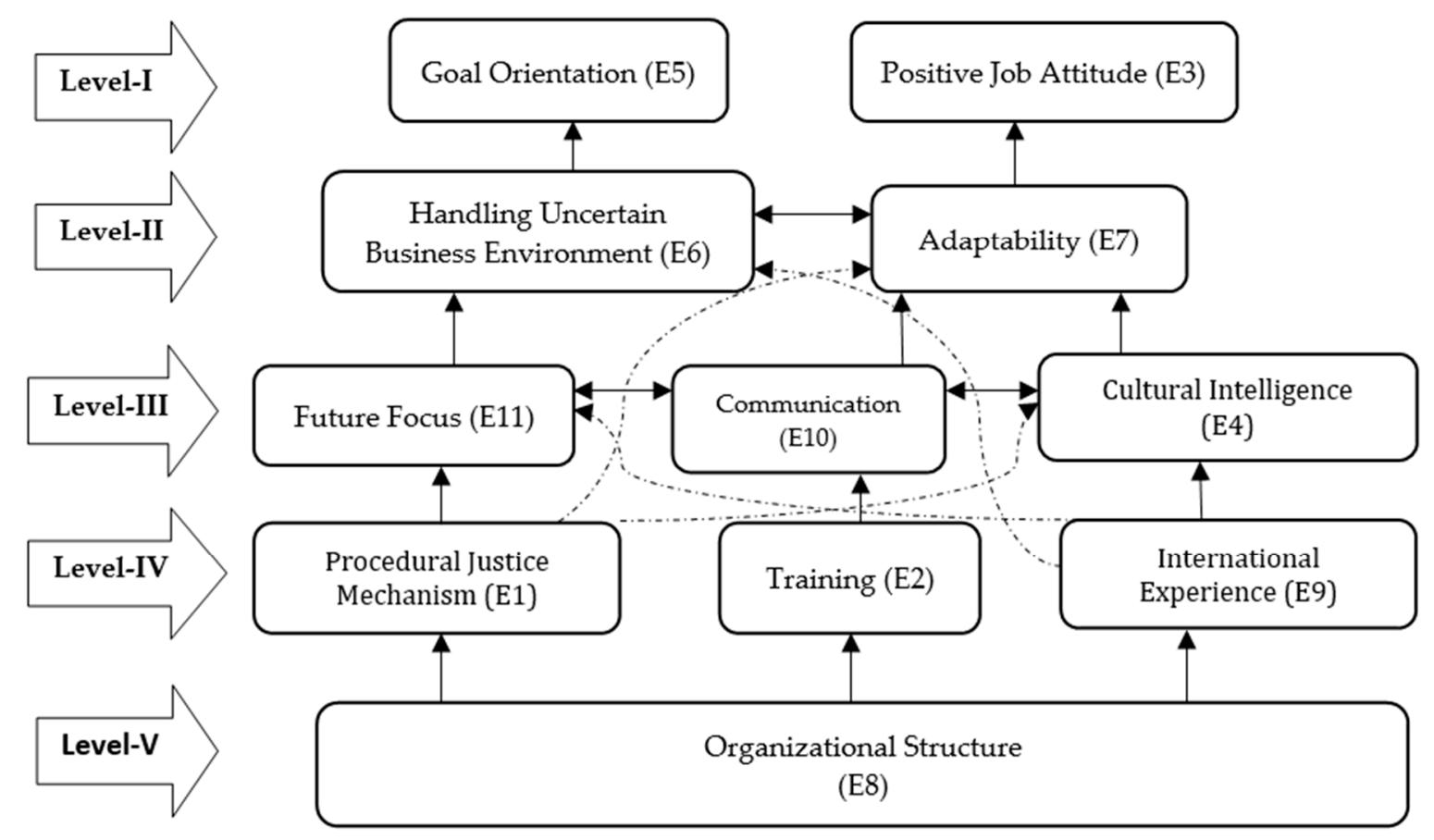

Figure 1. TISM model for the enablers of transformational leadership.

\section{Discussion of the Results (TISM Model)}

The basic objective of this study was to identify various enablers of TLD and understand the interrelationships among them that would positively affect the development of transformational leaders in megaprojects. The TISM-based model describes the relationship directions, where the links interpret in what way one enabler leads to another. Table 2 shows the SSIM. It presents the contextual relationship between two enablers, and Table 3 represents the final reachability matrix with ' 1 ' and ' 0 ' depending upon the symbols $\mathrm{V}, \mathrm{A}, \mathrm{X}$ and $\mathrm{O}$, and also includes the transitive relationship, represented by 1 * Table 4 represents the level partitioning for the enablers for transformational leadership development. Level I consists of two enablers: 'positive job attitude (E3)' and 'goal orientation (E5)'. These enablers are not influenced by each other and are the outcomes. Positive job attitude is important, as it motivates workers to go beyond their job assignments [54]. In the same vein, employees with goal orientation positively contribute to the organisation, as they try to learn new things, leading to improvements in their competences [68]. This implies that there are two dependent outcomes in the form of goal orientation and positive job attitude when improving TLD enablers in the organisation.

Level-II contains another two enablers: 'handling uncertain business environment (E6)' and 'adaptability (E7)'. Employees who are adaptable can easily understand situations and act accordingly [79], while handling uncertain business situations provides a variety of experiences, leading to improved adaptability [76]. On the other hand, adaptability facilitates innovative learning, which enables effective handling of uncertainty. Furthermore, enabler E6 also influences the first-level enabler 'goal orientation (E5)', meaning that handling the uncertain business environment provides opportunities to understand new things, thereby improving goal orientation. Enabler E7 influences the first-level enabler 'positive job attitude and satisfaction (E3)', meaning that adaptability provides motivation for achievement, leading to positive attitude and satisfaction.

Level-III consists of the enablers 'cultural intelligence (E4)', 'communication (E10)' and 'future focus (focus on future outcomes/consequences) (E11)'. Enabler E4 influences the same-level factors E10 and E11, meaning that understanding of the diversity of organisations and cultural values facilitates communication, as well as the ability to adapt to a variety of cultures [59], thus supporting future focus, as a leader can evaluate the outcomes 
more easily [64]. Similarly, enabler E10 influences enablers E4 and E11, while enabler E11 influences enablers E4 and E10. This implies that communication among employees provides opportunities to understand people from a variety of cultures, thereby improving their cultural intelligence, and an open two-way communication system supports feedback that would make it easier for employees to evaluate the future outcomes of their present behaviours. Furthermore, enabler E4 affects the second-level enabler 'adaptability (E7)'; this is possible because transformational leaders act as role models [64], thereby helping employees to appreciate a variety of cultures and their values. This improves their openness to experience and adaptability. Enabler E10 alters the second-level enabler 'adaptability (E7)', suggesting that communication supports openness to experience, which is a key enabler of adaptability. Enabler E11 influences the second-level enabler 'handling uncertain business environment (E6)', indicating that future focus helps leaders to consider future outcomes of their present behaviour [112]. This would assist in handling uncertain business environments.

Level-IV consists of another three enablers: 'procedural justice mechanism (E1)', 'training (E2)' and 'international experience (E9)'. Enabler E1 improves the third-level enabler 'future focus (focus on future outcomes/consequences) (E11)', suggesting that leaders will only be able to create team goals and set high standards when procedural justice exists in the organisation, while enabler E2 influences the third-level enabler 'communication (E10)', implying that formal training helps employees understand the merits of effective communication. It also helps employees to understand the channels/mechanisms that facilitate communication among themselves in order to improve organisational outcomes. In addition, enabler E9 affects the enabler 'cultural intelligence (E4)', the third-level enabler indicating that working on international assignments helps employees appreciate the values of various cultures, leading to an improvement in their cultural intelligence. This establishes the role of international experience as an intermediate variable [101], one that is influenced by lower-level variables, and in turn influences variables above it.

Finally, level-V contains only one enabler: 'organisational structure (E8)'. Enabler E8 influences the fourth-level enablers 'procedural justice mechanism (E1)', 'training (E2)' and 'international experience (E9)'. This finding supports the findings of [88,89], which consider organisational structure to be strongly correlated with leadership effectiveness. This implies that organisation structure, which consists of the formalisation of rules, facilitates the procedural justice mechanism, as employees can refer back to rules and understand the decision made in a specific situation, the distribution of authority in an organisational structure, and the mechanisms that provide employees with a chance to work on international projects based solely on merit. Furthermore, enabler E8 also influences the third- and fourth-level enablers 'handling uncertain business environment (E6)' and 'future focus (focus on future outcomes/consequences) (E11)', thereby indicating that organisational structure facilitates the distribution of power and positions within the organisation, supporting the findings of $[97,98]$. This fosters team goals and leads to the setting of high standards.

\section{MICMAC Analysis}

Cross-impact matrix multiplication applied to classification is abbreviated as 'MIC$M A C^{\prime}$. Its purpose is to analyse the driving power and dependence of enablers [122,124]. This is done to locate the critical enablers that drive the whole system under consideration. The final RM was used to build MICMAC grid by summing up all values of ' 1 ' in each row of the final RM, representing the driving power of that particular enabler. Similarly, adding all values of ' 1 ' in each column in the final RM represents the dependence of that particular enabler. These driving and dependence powers are than plotted in the form of a grid or matrix, as shown in Figure 2. Based on enablers' driving and dependence powers, the enablers in the present study were categorized into four clusters as follows:

1. Cluster I: contains autonomous enablers. These enablers have weak dependence and weak driving power and are relatively disconnected from the system, with which 
they have few links, which may be very strong. In the present study, there are no autonomous enablers, implying that the system is stable.

2. Cluster II: consists of dependent enablers that have weak driving power but strong dependence. In this study, there are four dependent enablers. They are: 'positive job attitude and satisfaction (E3)', 'goal orientation (E5)', 'handling uncertain business environment (E6)' and 'adaptability (E7)', as they exhibit strong dependence but comparatively weak driving power.

3. Cluster III: includes the linkage enablers, which have both strong driving and dependence powers. These enablers are unstable, as any action on these enablers will have an effect on others, and also a feedback on themselves. In this study, there are three linkage enablers. They are: 'cultural intelligence (E4)', 'communication (E10)' and 'future focus (focus on future outcomes/consequences) (E10)'.

4. Cluster IV: consists of the independent enablers, which have strong driving power and weak dependence. These enablers drive other enablers and are not affected by other enablers, and are referred as key enablers, but they can significantly improve other enablers. In this study, there are four enablers that fall into this cluster. They are: 'procedural justice mechanism (E1)', 'training (E2)', 'organisational structure (E8)' and 'international experience (E9)'. These enablers plays a key role in the TLD in organisations dealing in megaprojects. Management needs to give high priority to these driving enablers, because changes in these enablers affect the other enablers.

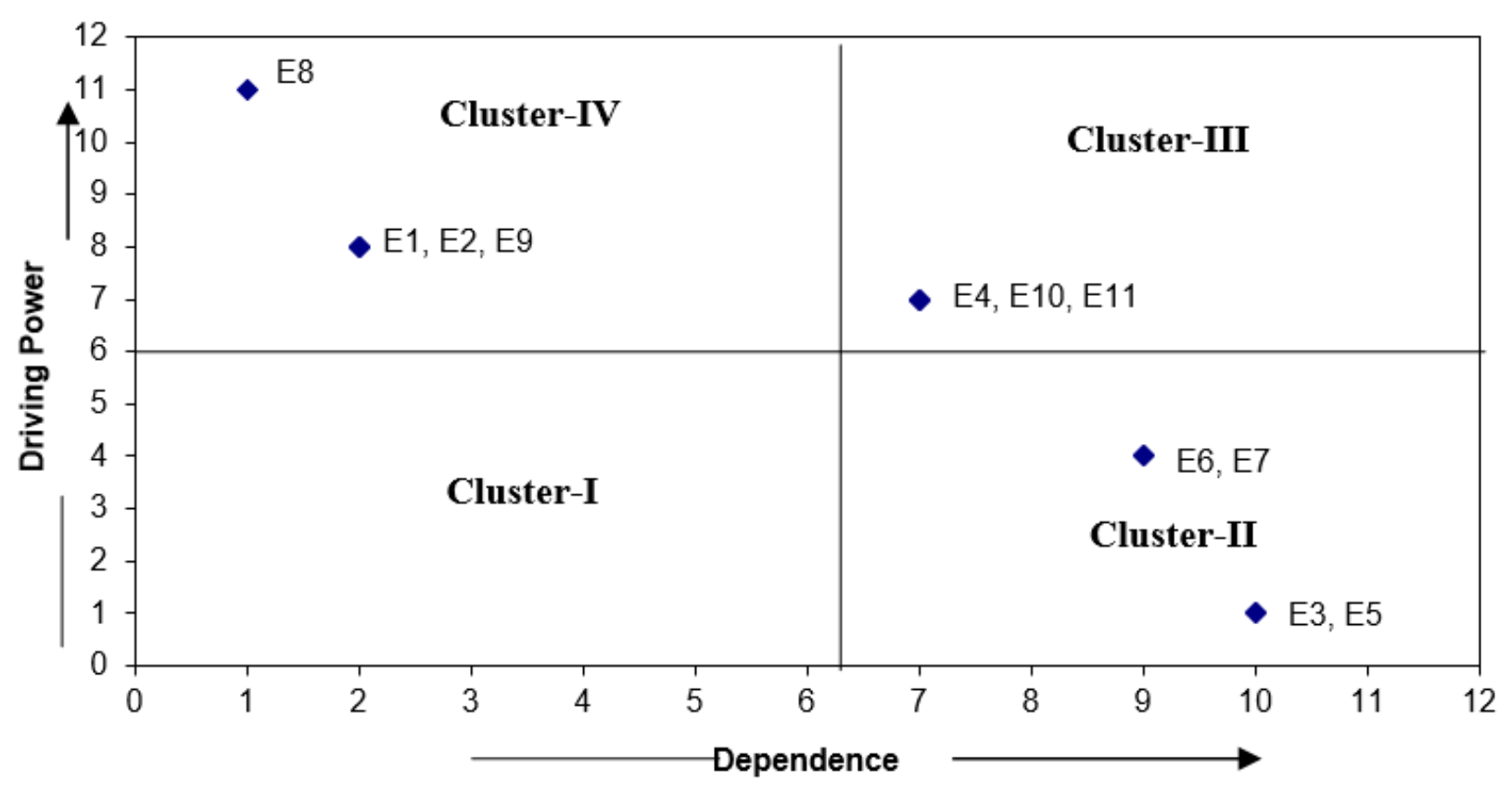

Figure 2. MICMAC analysis of enablers of transformational leadership development.

\section{Conclusions}

The present study helps mangers of megaprojects to identify the key enablers that contribute to TLD in megaprojects. In doing so, the study identified eleven key enablers that positively affect transformational leadership and developed an interrelationship model. Enablers influencing the TLD in megaprojects were identified based on a literature review and experts' opinions, and finally a TISM model was developed. Interpretive statements were also derived based on interpretive logic-knowledge. Furthermore, the MICMAC analysis tool was used in this study to classify the identified enablers into four categories, i.e., autonomous, dependence, linkage and independent enablers based on the driving and dependence powers of enablers. The major findings were as follows: 
- The findings of the study reiterate the fundamental proposition that 'procedural justice mechanism (E1)', 'training (E2)', 'organisational structure (E8)' and 'international experience (E9)' are the significant antecedents of TLD in megaprojects. The qualitative modelling thus validated the significance of these enablers, which were derived from review of the literature and from the viewpoints of industry experts.

- TISM results indicated that all enablers of the present study were considered important by the experts and play a role in transformational leadership development in megaprojects. Based on the data collected on the basis of expert opinion and their further interpretation, these enablers were partitioned into five levels.

- There were four independent enablers in the study, i.e., 'procedural justice mechanism $(\mathrm{E} 1)^{\prime}$ ', 'training (E2)', 'organisational structure (E8)' and 'international experience (E9)', that acted as drivers for the dependent enablers, i.e., 'positive job attitude and satisfaction (E3)', 'goal orientation (E5)', 'handling uncertain business environment (E6)' and 'adaptability (E7)'. These dependent enablers were also influenced by linkage enablers, i.e., 'cultural intelligence (E4)', 'communication (E10)' and 'future focus (focus on future outcomes/consequences) (E10)'.

- 'Positive job attitude (E3)' and 'goal orientation (E5)' were found to have the strongest dependence power, clearly justifying these as the outcome for the present TISM model. 'Procedural justice mechanism (E1)', 'training (E2)', 'organisational structure (E8)' and 'international experience (E9)' were found to be the key driving forces for the 'positive job attitude and satisfaction (E3)' and 'goal orientation (E5)' outcomes.

- Additionally, 'future focus (focus on future outcomes/consequences) (E11)', 'international experience (E9)', 'handling uncertain business environment (E6)', 'procedural justice mechanism (E1)', 'adaptability (E7)' and 'procedural justice mechanism (E1)', 'cultural intelligence (E4)' held a transitive relation with these enablers, while all other enablers had a direct influence.

- Based on the data collected from experts through TISM, a structural hierarchical model of the enablers that influence 'positive job attitude and satisfaction (E3)' and 'goal orientation (E5)' in the megaprojects was developed. Each enabler was compared with all other enablers, and their interaction was defined through knowledge-base logic statements.

- $\quad$ MICMAC analysis indicated that four enablers were dependent and four enablers were driving in the system under consideration. The novelty of this study is the development of a hierarchical level among the enablers to show the most influential enablers that drive all other enablers.

\subsection{Theoretical Contributions of the Study}

This study provides a unique model that brings together various elements of transformational leadership development in the context of megaprojects. Although several studies can be found in the existing literature on the importance of transformational leadership, none of the previous studies has attempted to propose a model of variables that opens new vistas of research. A systematic literature review alone cannot serve the purpose of finding the linkages between various factors. Hence, the TISM methodology was applied to interpret and extract the interrelationships among the factors that positively influence transformational leadership development.

\subsection{Practical Contributions of the Study}

Organisations dealing in megaprojects are always looking for leaders that have transformational leadership qualities, as transformational leaders have traits that can influence workers to achieve the goals of the project. However, organisations should focus on in order to inculcate transformational leadership attributes in their prospective leaders is not clear. The present study fills this gap by providing a structural model that advances understanding of the role of the most influential factors affecting transformational leadership development, and their interrelationships and relative significance in megaprojects. 
Practising managers in megaprojects organisations will find the model easy to understand. The model would help them to develop suitable strategies and to prioritize their efforts to improve the most significant variables for transformational leadership development, as delineated in the TISM model.

\section{Limitations and Scope for Future Research}

A major limitation of this study was the identification of the enablers of transformational leadership development in megaprojects on the basis of a literature review and a survey of experts. The experts considered for this study were working on megaprojects in Qatar, and therefore it is possible that their understanding of relationships may vary in other settings. Thereby, the results of this study can be evaluated in similar settings to validate the TISM model. A good environment for testing the model would be the United Arab Emirates, which has very similar demographic characteristics to Qatar and has several megaprojects underway. Furthermore, in future research, the TISM model can be tested using Partial Least Squares-based Structural Equation Modelling (PLS-SEM). PLS would be a better choice, as it is not easy to find many managers who have experience in megaprojects. In the current TISM model, all the relationships were equally weighted. Future research can also look into the varying the strength of the relationships using the Fuzzy-ISM technique. In addition, future work could also focus on quantifying the relative importance of the critical enablers by using techniques like Graph Theory.

Author Contributions: Conceptualisation, A.A.A.-S., M.N.F. and B.A.; Data curation, A.A.A.-S., M.N.F. and F.T.; Formal analysis, A.A.A.-S., M.N.F. and F.T.; Methodology, A.A.A.-S., M.N.F., B.A. and F.T.; Project administration, A.A.A.-S.; Resources, A.A.A.-S.; Supervision, M.N.F. and B.A.; Validation, A.A.A.-S., M.N.F., B.A. and F.T.; Writing—original draft, M.N.F. and F.T.; Writing-review \& editing, A.A.A.-S., M.N.F. and B.A. All authors have read and agreed to the published version of the manuscript.

Funding: This research received no external funding.

Institutional Review Board Statement: Not Applicable.

Informed Consent Statement: Not Applicable.

Data Availability Statement: All data used during the study are available from the corresponding author by request.

Acknowledgments: The authors would like to sincerely thank the two anonymous reviewers and the academic editor for their insightful comments, which has significantly improved the quality of the manuscript.

Conflicts of Interest: The authors declare no conflict of interest.

\section{References}

1. Flyvbjerg, B. What you should know about megaprojects and why: An overview. Proj. Manag. J. 2014, 45, 6-19. [CrossRef]

2. Denicol, J.; Davies, A.; Pryke, S. The organisational architecture of megaprojects. Int. J. Proj. Manag. 2021. [CrossRef]

3. Kardes, I.; Ozturk, A.; Cavusgil, S.T.; Cavusgil, E. Managing global megaprojects: Complexity and risk management. Int. Bus. Rev. 2013, 22, 905-917. [CrossRef]

4. Cerić, A.; Vukomanović, M.; Ivić, I.; Kolarić, S. Trust in megaprojects: A comprehensive literature review of research trends. Int. J. Proj. Manag. 2020. [CrossRef]

5. Priemus, H.; Flyvbjerg, B.; van Wee, B. (Eds.) Decision-Making on Mega-Projects: Cost-Benefit Analysis, Planning and Innovation; Edward Elgar Publishing: Cheltenham, UK, 2008.

6. Kasapoğlu, E. Leadership Styles in Architectural Design Offices in Turkey. J. Constr. Eng. Manag. 2014, 140, 04013047. [CrossRef]

7. Yang, L.R.; Huang, C.F.; Wu, K.S. The association among project manager's leadership style, teamwork and project success. Int. J. Proj. Manag. 2001, 29, 258-267. [CrossRef]

8. Dulewicz, V.; Higgs, M. Assessing leadership styles and organizational context. J. Manag. Psychol. 2005, 20, 105-123. [CrossRef]

9. Smith, G.R. Project leadership: Why project management alone doesn't work. Hosp. Mater. Manag. Q. 1999, $21,88$.

10. Aga, D.; Noorderhaven, N.; Vallejo, B. Transformational leadership and project success: The mediating role of team-building. Int. J. Proj. Manag. 2016, 34, 806-818. [CrossRef]

11. Jiang, J. The study of the relationship between leadership style and project success. Am. J. Trade Policy 2014, 1, 51-55. [CrossRef] 
12. Lloyd-Walker, B.; Walker, D. Authentic leadership for 21st century project delivery. Int. J. Proj. Manag. 2011, 29, 383-395. [CrossRef]

13. Nixon, P.; Harrington, M.; Parker, D. Leadership performance is significant to project success or failure: A critical analysis. Int. J. Prod. Perform. Manag. 2012, 61, 204-216. [CrossRef]

14. Brunet, M. Making sense of a governance framework for megaprojects: The challenge of finding equilibrium. Int. J. Proj. Manag. 2020. [CrossRef]

15. He, Q.; Chen, X.; Wang, G.; Zhu, J.; Yang, D.; Liu, X.; Li, Y. Managing social responsibility for sustainability in megaprojects: An innovation transitions perspective on success. J. Clean. Prod. 2019, 241, 118395. [CrossRef]

16. Islam, M.N.; Furuoka, F.; Idris, A. Mapping the relationship between transformational leadership, trust in leadership and employee championing behavior during organizational change. Asia Pac. Manag. Rev. 2020. [CrossRef]

17. Wang, G.; He, Q.; Meng, X.; Locatelli, G.; Yu, T.; Yan, X. Exploring the impact of megaproject environmental responsibility on organizational citizenship behaviors for the environment: A social identity perspective. Int. J. Proj. Manag. 2017, 35, 1402-1414. [CrossRef]

18. Wang, G.; Wu, P.; Wu, X.; Zhang, H.; Guo, Q.; Cai, Y. Mapping global research on sustainability of megaproject management: A scientometric review. J. Clean. Prod. 2020, 259, 120831. [CrossRef]

19. Lin, X.; McKenna, B.; Ho, C.M.; Shen, G.Q. Stakeholders influence strategies on social responsibility implementation in construction projects. J. Clean. Prod. 2019, 235, 348-358. [CrossRef]

20. Carvajal-Arango, D.; Bahamón-Jaramillo, S.; Aristizábal-Monsalve, P.; Vásquez-Hernández, A.; Botero, L.F.B. Relationships between lean and sustainable construction: Positive impacts of lean practices over sustainability during construction phase. $J$. Clean. Prod. 2019, 234, 1322-1337. [CrossRef]

21. Mittal, S.; Dhar, R.L. Effect of green transformational leadership on green creativity: A study of tourist hotels. Tour. Manag. 2016, 57, 118-127. [CrossRef]

22. Müller, R.; Turner, J.R. Attitudes and leadership competences for project success. Balt. J. Manag. 2010, 5, 307-329. [CrossRef]

23. Bass, B.M. Leadership: Good, better, best. Organ. Dyn. 1985, 13, 26-40. [CrossRef]

24. Arnold, G.E. Examining the Relationship between Leadership Style and Project Success in Virtual Projects; University of Phoenix: Phoenix, AZ, USA, 2008.

25. Ammeter, A.P.; Dukerich, J.M. Leadership, Team Building, and Team Member Characteristics in High Performance Project Teams. Eng. Manag. J. 2002, 14, 3-10. [CrossRef]

26. Keller, R.T. Transformational Leadership and the Performance of Research and Development Project Groups. J. Manag. 1992, 18, 489-501. [CrossRef]

27. Ahmadabadi, A.A.; Heravi, G. Risk assessment framework of PPP-megaprojects focusing on risk interaction and project success. Transp. Res. Part A Policy Pract. 2019, 124, 169-188. [CrossRef]

28. Kissi, J.; Dainty, A.; Tuuli, M. Examining the role of transformational leadership of portfolio managers in project performance. Int. J. Proj. Manag. 2013, 31, 485-497. [CrossRef]

29. Jensen, M.; Potočnik, K.; Chaudhry, S. A mixed-methods study of CEO transformational leadership and firm performance. Eur. Manag. J. 2020, 38, 836-845. [CrossRef]

30. Tyssen, A.K.; Wald, A.; Spieth, P. The challenge of transactional and transformational leadership in projects. Int. J. Proj. Manag. 2014, 32, 365-375. [CrossRef]

31. Aarseth, W.; Rolstadås, A.; Klev, R. Project Leadership Challenges. Their Nature and How They Are Managed; Fagbokforlaget: Bergen, Norway, 2016; ISBN 9788245021301.

32. Zaman, U.; Nawaz, S.; Tariq, S.; Humayoun, A.A. Linking transformational leadership and "multi-dimensions" of project success: Moderating effects of project flexibility and project visibility using PLS-SEM. Int. J. Manag. Proj. Bus. 2019, 13, 103-127. [CrossRef]

33. Thite, M. Leadership styles in information technology projects. Int. J. Proj. Manag. 2000, 18, 235-241. [CrossRef]

34. Shamir, B.; House, R.J.; Arthur, M.B. The Motivational Effects of Charismatic Leadership: A Self-Concept Based Theory. Organ. Sci. 1993, 4, 577-594. [CrossRef]

35. Hertogh, M.; Baker, S.; Staal-Ong, P.L.; Westerveld, E. Managing Large Infrastructure Projects: Research on Best Practice Lessons Leant in Large Infrastructure Projects in Europe; AT Osborne: Utrecht, The Netherland, 2008.

36. House, R.J. Path-goal theory of leadership: Lessons, legacy, and a reformulated theory. Lead. Q. 1996, 7, 323-352. [CrossRef]

37. Yammarino, F.J.; Spangler, W.D.; Bass, B.M. Transformational leadership and performance: A longitudinal investigation. Lead. Q. 1993, 4, 81-102. [CrossRef]

38. Greenberg, J. Managing Behaviour in Organizations; Prentice Hall: Upper Saddle River, NJ, USA, 2005.

39. Dulebohn, J.H.; Bommer, W.H.; Liden, R.C.; Brouer, R.L.; Ferris, G.R. A meta-analysis of antecedents and consequences of leader-member exchange: Integrating the past with an eye toward the future. J. Manag. 2012, 38, 1715-1759. [CrossRef]

40. De Cremer, D.; Tyler, T.R. Managing group behavior: The interplay between procedural fairness, sense of self, and cooperative behavior. In Advances in Experimental Social Psychology; Zanna, M., Ed.; Elsevier Science: New York, NY, USA, 2005; Volume 37, pp. 151-218.

41. Smith, H.J.; Tyler, T.R. Choosing the Right Pond: The Impact of Group Membership on Self-Esteem and Group-Oriented Behavior. J. Exp. Soc. Psychol. 1997, 33, 146-170. [CrossRef]

42. Tyler, T.R. Why people cooperate with organizations: An identity-based perspective. Res. Organ. Behav. 1999, $21,201-246$. 
43. Abrell, C.; Rowold, J.; Weibler, J.; Moenninghoff, M. Evaluation of a long-term transformational leadership development program. Ger. J. Hum. Resour. Manag. 2011, 25, 205-224. [CrossRef]

44. Bass, B.M.; Avolio, B.J. Developing Transformational Leadership: 1992 and Beyond. J. Eur. Ind. Train. 1990, 14, 22-27. [CrossRef]

45. Howell, J.M.; Frost, P.J. A laboratory study of charismatic leadership. Organ. Behav. Hum. Decis. Process. 1989, 43, 243-269. [CrossRef]

46. Kirkpatrick, S.A.; Locke, E.A. Direct and indirect effects of three core charismatic leadership components on performance and attitudes. J. Appl. Psychol. 1996, 81, 36. [CrossRef]

47. Barling, J.; Weber, T.; Kelloway, E.K. Effects of transformational leadership training on attitudinal and financial outcomes: A field experiment. J. Appl. Psychol. 1996, 81, 827. [CrossRef]

48. Kelloway, E.K.; Barling, J.; Helleur, J. Enhancing transformational leadership: The roles of training and feedback. Leadersh. Organ. Dev. J. 2000. [CrossRef]

49. Jin, S.; Seo, M.-G.; Shapiro, D.L. Do happy leaders lead better? Affective and attitudinal antecedents of transformational leadership. Lead. Q. 2016, 27, 64-84. [CrossRef]

50. Ilies, R.; Scott, B.A.; Judge, T.A. The Interactive Effects of Personal Traits and Experienced States on Intraindividual Patterns of Citizenship Behavior. Acad. Manag. J. 2006, 49, 561-575. [CrossRef]

51. Longshore, J.M.; Bass, B.M. Leadership and Performance beyond Expectations. Acad. Manag. Rev. 1987, 12, 756. [CrossRef]

52. Fox, S.; Spector, P.E.; Goh, A.; Bruursema, K.; Kessler, S.R. The deviant citizen: Measuring potential positive relations between counterproductive work behavior and organizational citizenship behavior. J. Occup. Organ. Psychol. 2012, 85, 199-220. [CrossRef]

53. Smith, C.A.; Organ, D.W.; Near, J.P. Organizational citizenship behavior: Its nature and antecedents. J. Appl. Psychol. 1983, 69, 653-663. [CrossRef]

54. Eisenberger, R.; Armeli, S.; Rexwinkel, B.; Lynch, P.D.; Rhoades, L. Reciprocation of perceived organizational support. J. Appl. Psychol. 2001, 86, 42-51. [CrossRef] [PubMed]

55. Elliott, A.J.; Devine, P.G. On the motivational nature of cognitive dissonance: Dissonance as psychological discomfort. J. Personal. Soc. Psychol. 1994, 65, 382-394. [CrossRef]

56. Skarlicki, D.P.; Folger, R.; Tesluk, P. Personality as a moderator in the relationship between fairness and retaliation. Acad. Manag. J. 1999, 42, 100-108.

57. Steers, R.M.; Sanchez-Runde, C.; Nardon, L. Leadership in a global context: New directions in research and theory development. J. World Bus. 2012, 47, 479-482. [CrossRef]

58. Earley, P.; Ang, S. Cultural Intelligence: Individual Interactions across Cultures; Stanford Business Books: Stanford, CA, USA, 2003; Volume 1.

59. Earley, P. Redefining interactions across cultures and organizations: Moving forward with cultural intelligence. Res. Organ. Behav. 2002, 24, 271-299. [CrossRef]

60. Ng, K.-Y.; Tan, M.; Ang, S. Global culture capital and cosmopolitan human capital. In The Oxford Handbook of Human Capital; Burton-Jones, A., Spender, J.C., Eds.; Oxford University Press: Oxford, UK, 2011; pp. 96-119.

61. Gurung, A.; Prater, E. A Research Framework for the Impact of Cultural Differences on IT Outsourcing. J. Glob. Inf. Technol. Manag. 2006, 9, 24-43. [CrossRef]

62. Blumberg, H.H. Small Group Research: Implications for Peace Psychology and Conflict Resolution; Springer: New York, NY, USA, 2011.

63. Ramsey, J.R.; Rutti, R.M.; Lorenz, M.P.; Barakat, L.L.; Sant'anna, A.S. Developing global transformational leaders. J. World Bus. 2017, 52, 461-473. [CrossRef]

64. Elenkov, D.S.; Manev, I.M. Senior expatriate leadership's effects on innovation and the role of cultural intelligence. J. World Bus. 2009, 44, 357-369. [CrossRef]

65. Seijts, G.H.; Latham, G.P.; Tasa, K.; Latham, B.W. Goal setting and goal orientation: An integration of two yet related literatures. Acad. Manag. J. 2004, 47, 227-239.

66. Pastor, J.C.; Mayo, M. Transformational leadership among Spanish upper echelons. Lead. Organ. Dev. J. 2008, 29, 340-358. [CrossRef]

67. Domingues, J.; Vieira, V.A.; Agnihotri, R. The interactive effects of goal orientation and leadership style on sales performance. Mark. Lett. 2017, 28, 637-649. [CrossRef]

68. Dweck, C.S.; Leggett, E.L. A social-cognitive approach to motivation and personality. Psychol. Rev. 1988, 2, 256-273. [CrossRef]

69. Dweck, C.S. Capturing the Dynamic Nature of Personality. J. Res. Pers. 1996, 30, 348-362. [CrossRef]

70. Dweck, C.S. Motivation. In Foundations for a Psychology of Education; Lesgold, A., Glaser, R., Eds.; Erlbaum: Hillsdale, NJ, USA, 1989; pp. 87-136.

71. Tabernero, C.; Wood, R.E. Implicit Theories versus the Social Construal of Ability in Self-Regulation and Performance on a Complex Task. Organ. Behav. Hum. Decis. Process. 1999, 78, 104-127. [CrossRef] [PubMed]

72. Evans, M.G. Extensions of a path-goal theory of motivation. J. Appl. Psychol. 1974, 59, 172-178. [CrossRef]

73. Miller, D.; Droege, D.; Toulouse, J. Strategic process and contents as mediators between organizational context and structure. Acad. Manag. J. 1988, 31, 544-569.

74. Drazin, R.; Schoonhoven, C.D. Community, population, and organization effects on innovation: A multilevel perspective. Acad. Manag. J. 1996, 39, 1064-1083. 
75. Fulmer, R.M.; Gibbs, P.A.; Goldsmith, M. Developing leaders: How winning companies keep on winning. Sloan Manag. Rev. 2020, 42, 49-59.

76. Beugré, C.D.; Acar, W.; Braun, W. Transformational leadership in organizations: An environment-induced model. Int. J. Manpow. 2006, 27, 52-62. [CrossRef]

77. Hill, M.A. The new frontier: Transformation of management for the new millennium. Organ. Dyn. 2000, 7-17.

78. Avolio, B.J.; Bass, B.M. Transformational Leadership, Charisma, and Beyond; American Psychological Association: Washington, DC, USA, 1988.

79. Lepine, J.A.; Colquitt, J.A.; Erez, A. Adaptability to changing task contexts: Effects of general cognitive ability, conscientiousness, and openness to experience. Pers. Psychol. 2000, 53, 563-593. [CrossRef]

80. Costa, P.T.; McCrae, R.R. The NEO-PI/NEO-FFI Manual Supplement; Psychological Assessment Resources: Odessa, FL, USA, 1989.

81. Keller, T. Images of the familiar: Individual differences and implicit leadership theories. Leadersh. Q. 1999, 10, 589-607. [CrossRef]

82. Hofstee, W.K.; de Raad, B.; Goldberg, L.R. Integration of the Big Five and circumplex approaches to trait structure. J. Personal. Soc. Psychol. 1992, 63, 146-163. [CrossRef]

83. Komarraju, M.; Karau, S.J.; Schmeck, R.R. Role of the Big Five personality traits in predicting college students' academic motivation and achievement. Learn. Individ. Differ. 2009, 19, 47-52. [CrossRef]

84. Brummelhuis, L.L.T.; Bakker, A.B. A resource perspective on the work-home interface: The work-home resources model. Am. Psychol. 2012, 67, 545-556. [CrossRef]

85. Hildenbrand, K.; Sacramento, C.A.; Binnewies, C. Transformational leadership and burnout: The role of thriving and follower's openness to experience. J. Occup. Health Psychol. 2018, 23, 31. [CrossRef] [PubMed]

86. Bartram, D. The Great Eight Competencies: A Criterion-Centric Approach to Validation. J. Appl. Psychol. 2005, 90, 1185-1203. [CrossRef] [PubMed]

87. Judge, T.A.; Cable, D.M. Applicant personality, organizational culture, and organization attraction. Pers. Psychol. 1997, 50, 359-394. [CrossRef]

88. Stogdill, R.M.; Katz, D.; Kahn, R.L. The Social Psychology of Organizations. Am. J. Psychol. 1967, 80, 480. [CrossRef]

89. Pawar, B.S.; Eastman, K.K. The nature and implications of contextual influences on transformational leadership: A conceptual examination. Acad. Manag. Rev. 1997, 22, 80-109. [CrossRef]

90. Wright, B.E.; Pandey, S.K. Transformational Leadership in the Public Sector: Does Structure Matter? J. Public Adm. Res. Theory 2009, 20, 75-89. [CrossRef]

91. Ambrose, M.L.; Schminke, M. Organization structure as a moderator of the relationship between procedural justice, interactional justice, perceived organizational support, and supervisory trust. J. Appl. Psychol. 2003, 88, 295-305. [CrossRef]

92. Daft, R.L. Essentials of Organization Theory and Design; South Western Educational Publishing: Cincinnati, OH, USA, 1998.

93. James, L.R.; Jones, A.P. Organizational structure: A review of structural dimensions and their conceptual relationships with individual attitudes and behavior. Organ. Behav. Hum. Perform. 1976, 16, 74-113. [CrossRef]

94. DumDum, U.R.; Lowe, K.B.; Avolio, B.J. A Meta-Analysis of Transformational and Transactional Leadership Correlates of Effectiveness and Satisfaction: An Update and Extension. In Monographs in Leadership and Management; Emerald: Bingley, UK, 2013; pp. 39-70.

95. Lowe, K.B.; Kroeck, K.; Sivasubramaniam, N. Effectiveness correlates of transformational and transactional leadership: A meta-analytic review of the mlq literature. Lead. Q. 1996, 7, 385-425. [CrossRef]

96. Mumford, M.D.; Antes, A.L.; Caughron, J.J.; Friedrich, T.L. Charismatic, ideological, and pragmatic leadership: Multi-level influences on emergence and performance. Lead. Q. 2008, 19, 144-160. [CrossRef]

97. Howell, J.M. Organization Contexts, Charismatic and Exchange Leadership. Kellogg Leadership Studies Monograph. Center for Political Leadership and Participation; University of Maryland: College Park, MD, USA, 1997.

98. Shamir, B.; Howell, J.M. Organizational and contextual influences on the emergence and effectiveness of charismatic leadership. Leadersh. Q. 1999, 10, 257-283. [CrossRef]

99. Gundersen, G.; Hellesøy, B.; Raeder, S. Leading international project teams: The effectiveness of transformational leadership in dynamic work environments. J. Leadersh. Organ. Stud. 2012, 19, 46-57. [CrossRef]

100. Van Woerkom, M.; De Reuver, R.S. Predicting excellent management performance in an intercultural context: A study of the influence of multicultural personality on transformational leadership and performance. Int. J. Hum. Resour. Manag. 2009, 20, 2013-2029. [CrossRef]

101. Ang, S.; Van Dyne, L.; Rockstuhl, T. Cultural intelligence: Origins, conceptualization, evolution, and methodological diversity. Handb. Adv. Cult. Psychol. 2015, 5, 1-45.

102. Pless, N.M.; Maak, T.; Stahl, G.K. Developing responsible global leaders through international service-learning programs: The Ulysses experience. Acad. Manag. Learn. Educ. 2011, 10, 237-260.

103. Şahin, F.; Gürbüz, S.; Şeşen, H. Leaders' managerial assumptions and transformational leadership: The moderating role of gender. Leadersh. Organ. Dev. J. 2017. [CrossRef]

104. Carpenter, M.; Sanders, G.; Gregersen, H. Bundling human capital with organizational context: The impact of international assignment experience on multinational firm performance and CEO pay. Acad. Manag. J. 2001, 44, 493-511.

105. Men, L.R. Why Leadership Matters to Internal Communication: Linking Transformational Leadership, Symmetrical Communication, and Employee Outcomes. J. Public Relat. Res. 2014, 26, 256-279. [CrossRef] 
106. Hackman, M.Z.; Johnson, C.E. Leadership: A Communication Perspective, 4th ed.; Waveland: Long Grove, IL, USA, 2004.

107. Berson, Y.; Avolio, B.J. Transformational leadership and the dissemination of organizational goals: A case study of a telecommunication firm. Lead. Q. 2004, 15, 625-646. [CrossRef]

108. Barge, J.K. Leadership Communication Skills for Organizations and Groups; St. Martin's Press: New York, NY, USA, 1994.

109. Flauto, F.J. The Relationships among Transactional Leadership, Transformational Leadership, Quality of Leader-Member Exchange, and Communicative Competence: An Integrated Model; Ohio University: Ann Arbor, MI, USA, 1994.

110. Lvina, E. The Role of Cross-Cultural Communication Competence: Effective Transformational Leadership Across Cultures. J. Ilm. Peuradeun 2015, 3, 1-18.

111. Joireman, J.; Strathman, A.; Balliet, D. Considering future consequences: An integrative model. In Judgments over Time: The Interplay of Thoughts, Feelings, and Behaviors; Sanna, L., Change, E., Eds.; Oxford University Press: Oxford, UK, 2006 ; pp. 82-99.

112. Jansen, J.J.P.; Vera, D.; Crossan, M. Strategic leadership for exploration and exploitation: The moderating role of environmental dynamism. Leadersh. Q. 2009, 20, 5-18. [CrossRef]

113. Zhang, W.; Wang, H.; Pearce, C.L. Consideration for future consequences as an antecedent of transformational leadership behavior: The moderating effects of perceived dynamic work environment. Lead. Q. 2014, 25, 329-343. [CrossRef]

114. Mohanty, M. Assessing sustainable supply chain enablers using total interpretive structural modeling approach and fuzzyMICMAC analysis. Manag. Env. Qual. Int. J. 2018, 29, 216-239. [CrossRef]

115. Swarnakar, V.; Tiwari, A.K.; Singh, A. Evaluating critical failure factors for implementing sustainable lean six sigma framework in manufacturing organization. Int. J. Lean Six Sigma 2020, 11, 1083-1118. [CrossRef]

116. Vaishnavi, V.; Suresh, M.; Dutta, P. A study on the influence of factors associated with organizational readiness for change in healthcare organizations using TISM. Benchmark. Int. J. 2019, 26, 1290-1313. [CrossRef]

117. Sushil. How to check correctness of total interpretive structural models? Ann. Oper. Res. 2016, 270, 473-487. [CrossRef]

118. Talib, F.; Rahman, Z. Modeling the barriers towards the growth of higher education institutions: A total interpretive structural modeling approach. Qual. Res. J. 2020, 20, 243-264. [CrossRef]

119. Agrawal, R.; Vinodh, S. Application of total interpretive structural modelling (TISM) for analysis of factors influencing sustainable additive manufacturing: A case study. Rapid Prototyp. J. 2019, 25, 1198-1223. [CrossRef]

120. Singh, A.; Sushil. Developing a conceptual framework of waste management in the organizational context. Manag. Env. Qual. Int. J. 2017, 28, 786-806. [CrossRef]

121. Faisal, M.N.; Talib, F.; Bhutta, M.K. Enablers of Sustainable Solid Waste Management System in India. Int. J. Environ. Waste Manag. 2019, 23, 213-237. [CrossRef]

122. Al-Esmael, B.; Talib, F.; Faisal, M.N.; Jabeen, F. Socially responsible supply chain management in small and medium enterprises in the GCC. Soc. Responsib. J. 2019, 16, 369-386. [CrossRef]

123. Jabeen, F; Faisal, M.N.; Katsioloudes, M.I. Localisation in an emerging Gulf economy: Understanding the role of education, job attributes and analysing the barriers in its process. Equal. Divers. Incl. Int. J. 2018, 37, 151-166. [CrossRef]

124. Khan, H.; Talib, F.; Faisal, M.N. An analysis of the barriers to the proliferation of m-commerce in Qatar: A relationship modeling approach. J. Syst. Inf. Technol. 2015, 17, 54-81. [CrossRef] 